\title{
Media dan Produksi Bahasa pada Masa Pandemi Covid-19 di Indonesia
}

\author{
Romika Junaidi ${ }^{1}$, Didid Haryadi ${ }^{2}$ \\ 1,2Universitas Nasional \\ Email: romika@civitas.unas.ac.id
}

\begin{abstract}
This paper discusses the correlation between media and language during pandemic Covid-19 in Indonesia and how language construction and information flows from the level of the government to the people about social reality. The Indonesian government anticipated pandemic Covid-19 started from early 2020 with many regulations. The language gimmick between the government and the people is changing and struggling time by time. Due to language usable during the pandemic and the new normal phase, that was an interesting issue from the communication and the sociology perspectives. This paper is used Merton's theory about unintended consequences to reading all the problems about language during the pandemic. This research uses the qualitative method within the study case to explain the phenomena of language production during the pandemic. As the result of this paper, there is an inconsistent euphemism language from the government to the people in the middle class of economy. And so this may be called a government failure in the case of distribution of information and communication strategy during the pandemic Covid-19.
\end{abstract}

Keywords: Media; Covid-19; language production

\begin{abstract}
Abstrak: Penelitian ini membahas tentang media dan produksi bahasa selama pandemi Covid19 di Indonesia dan bagaimana konstruksi bahasa dan arus informasi dari tingkat pemerintah kepada masyarakat serta hubungannya dengan realitas sosial. Pemerintah Indonesia telah berusaha mengantisipasi fenomena pandemi Covid-19 sejak awal tahun 2020 beserta pelbagai macam regulasi yang dihasilkan. Gestur komunikasi antara pemerintah dan masyarakat menjadi berubah dan mengalami proses. Seiring dengan penggunaan bahasa selama pandemi dan fase adaptasi kebiasaan baru merupakan suatu isu yang menarik untuk dikaji dari perspektif ilmu komunikasi dan sosiologi. Tujuan penelitian ini adalah untuk memberikan paparan mengenai perkembangan produksi bahasa Indonesia dan interaksinya selama pandemi Covid-19. Penelitian ini menggunakan konsep dasar ala Merton yaitu unintended consequency untuk membaca fenomena yang sebelumnya tidak pernah terjadi seperti kasus wabah pandemi Covid19. Metode penelitian yang digunakan yaitu metode kualitatif dengan penggunaan studi kasus untuk menjelaskan fenomena produksi bahasa selama pandemi. Hasil simpulan penelitian ini yaitu terdapat inkonsistensi penggunaan bahasa yang menggunakan gaya bahasa eufimisme dari level pemerintah ke level masyarakat kelas ekonomi menengah. Dalam kata lain hal ini menjadi kegagalan pemerintah dalam hal distribusi informasi dan strategi komunikasi selama pandemi Covid-19.
\end{abstract}

Kata kunci: Media; Covid-19; produksi bahasa

\section{Pendahuluan}

Pandemi Covid-19 telah berdampak pada kehidupan sosial masyarakat secara luas. Baik berupa sisi ekonomi, politik, budaya, dan konsumsi. Sejak kemunculan Covid-19 di awal tahun 2020, segala bentuk preventif untuk memotong rantai penularannya telah dilakukan. Misalnya, 
dengan menerapkan gaya hidup yang sehat seperti membiasakan untuk mencuci tangan, mengenakan masker, menggunakan hand sanitizer, ataupun membatasi aktivitas di luar ruangan. Salah satu bentuk penegasan terhadap langkah pencegahan penularan virus Covid-19 adalah dengan mengeluarkan kebijakan, dimana pemerintah Indonesia menyebutnya dengan 'Pembatasan Sosial Berskala Besar' (PSBB). Pada awalnya, kebijakan PSBB hanya diberlakukan di episentrum Covid-19 ataupun wilayah dengan jumlah penularan yang tinggi seperti di Jakarta.

Studi bahasa dan pandemi sebelumnya telah digagas oleh beberapa pakar, diantaranya yakni Jacobsen (2018) dengan penelitian berjudul The Oxford Handbook of Global Studies yang memaparkan sejarah dan respon isu global pandemi yang melanda Amerika menggunakan studi kasus penyakit kolera, influenza, dan HIV AIDS. Retorika bahasa terkait pandemi digunakan seperti penggunaan kata obesitas yang hingga kini efektif digunakan terkait edukasi akibat dari penyakit. Hasil penelitian ini yaitu pandemi merupakan isu global gabungan dari bermacam interaksi dan proses yang termanifestasikan melalui bahasa. Penelitian lain mengenai bahasa dan pandemi yaitu Ingrid Piller, Jie Zhang dan Jia Lie tahun 2020 dengan judul Linguistic Diversity in The Time of Crisis: Language Challenges of the Covid-19 Pandemic yang memaparkan peran sentral bahasa Inggris terkait bahasa Tiongkok dalam tantangan bahasa selama pandemi Covid-19. Hasil penelitian ini menunjukkan peran bahasa Inggris lebih mudah digunakan karena bahasa Inggris secara rentang historis telah menjadi lingua franca bahasa pergaulan bangsa-bangsa di dunia.

Penelitian lain terkait bahasa dan pandemi Covid-19 oleh Suliman tahun 2021 dengan tajuk Impak Pandemik Covid-19 terhadap Bahasa, Sastra dan Budaya di Malaysia. Hasil penelitian ini membahas bagaimana dinamika perlintasan bahasa yang muncul akibat pandemi Covid-19 serta pengaruhnya terhadap penggunaan kata dalam tata bahasa dan sastra di Malaysia. Dalam penelitian ini juga dibahas mengenai progres kebudayaan yang ditampilkan melalui karya sastra yang mengusung tema utama pandemi Covid-19. Kajian lain terkait bahasa dan pandemi dalam konteks media sosial dapat dilihat dalam COVID-Twitter-BERT: A Natural Language Processing Model to Analyse COVID-19 Content on Twitter oleh Muller et al pada tahun 2020. Penelitian ini membahas perlintasan kata yang muncul di Twitter terkait pandemi Covid-19 menggunakan metode CT-BERT berisi analisis 160 juta kata dalam kurun waktu 12 Januari sampai dengan 16 April 2020. Algoritma Twitter mencatat perlintasan kata terkait pandemi Covid-19 yang memiliki dampak terhadap realitas sosial di masyarakat Amerika Serikat.

Bahasa mengambil peran penting dalam ihwal komunikasi manusia. Terlebih di saat pandemi Covid-19, publik dikejutkan dengan peristilahan baru yang sebelumnya kurang populer mengingat pandemi Covid-19 merupakan isu kolektif yang muncul di akhir tahun 2019 dan sebelumnya hanya diprediksi sebagai wabah biasa sebagaimana penyakit pada umumnya. Namun alih-alih, fakta di lapangan berbicara bahwa pandemi Covid-19 secara gamblang telah menghancurkan beberapa sektor pembangunan ekonomi, sosial, dan politik terutama yang terkait dengan dunia kesehatan. Dalam perkembangannya, kebijakan PSBB memunculkan istilah-istilah baru yang diperkenalkan kepada publik, misalnya Alat Perlindungan Diri (APD), Rapid Test, Swab Test, dan sebagainya. Terma-terma tersebut berkonsekuensi logis terhadap berubahnya perilaku dan gaya hidup masyarakat. Proses adaptasi terhadap bahasa tentu saja 
membutuhkan proses khusus dalam memaknainya. Adapun istilah paling baru, pemerintah menerapkan protokol kesehatan yang disebut kondisi adaptasi tatanan baru untuk membaur bersama virus Covid-19 dengan tetap memperhatikan rambu-rambu kesehatan. Selanjutnya, pemerintah meresmikan istilah tersebut menjadi 'Adaptasi Kebiasaan Baru'.

Selama masa pandemi Covid-19, banyak perlintasan entri istilah-istilah baru yang dimunculkan kepada publik. Beberapa istilah yang sudah sangat populer, diantaranya adalah ODP (Orang Dalam Pemantauan), PDP (Pasien Dalam Pengawasan), OTG (Orang Tanpa Gejala), Suspect, PSBB, Social Distancing, Physical Distancing, dan sebagainya. Kurang lebih sekitar 20 hingga 27 istilah yang sampai saat ini telah diketahui oleh publik. Dalam rutinitas sosial yang telah terdampak teknologi, penggunaan istilah bahasa asing sudah dianggap sangat biasa. Bahkan dalam praktiknya terkadang pencampuran bahasa asing dengan bahasa Indonesia sudah dianggap lazim oleh penggunanya dengan pelbagai alasan.

Penggunaan istilah bahasa asing seolah menunjukkan adanya keakraban ritus keseharian individu atau kelompok terhadap perkembangan teknologi informasi sekaligus menegaskan bahwa era industrialisasi telah memberikan dampak yang signifikan kepada masyarakat. Secara sosiologis, fenomena-fenomena di atas dapat dianalisis dalam perspektif fungsional struktural. Merton (1936) memberikan dua narasi untuk menjelaskan dampak-dampak sosial yang ada dalam masyarakat, yakni melalui konsep unintended consequencies. Teori ini menunjukkan bahwa semua intervensi sosial memiliki konsekuensi yang tidak dimaksudkan, baik yang bisa ditebak maupun tidak. Contohnya, vaksinasi paksa yang dilaksanakan di India pada saat kampanye penghapusan cacar ternyata menimbulkan resistensi masyarakat terhadap kampanye vaksinasi yang lainnya. Teori ini membantu menunjukkan bahwa perlu dilakukan evaluasi secara rutin terhadap intervensi-intervensi kesehatan untuk memastikan konsekuensi kesengajaan tersebut dapat diatur melalui modifikasi atau bila perlu dengan opsi terminasi program.

Berdasarkan latar belakang di atas, penelitian ini berusaha melakukan analisis dan menemukan jawaban atas rumusan masalah yang telah ditentukan yaitu bagaimana efektifitas peran media sebagai kanal utama dari pemerintah dan korelasinya dengan bahasa Indonesia selama pandemi Covid-19 yang melibatkan pemerintah sebagai pemangku kebijakan kepada masyarakat sebagai audiens. Penelitian ini ingin memposisikan sebagai studi media terhadap pandemi Covid-19 melalui bidang komunikasi yang diinterpretasikan oleh bahasa sebagai alat komunikasi utama.

\section{Metode}

Metode penelitian yang digunakan dalam penelitian ini adalah kualitatif dengan mengambil studi kasus pada penyebaran dan penggunaan istilah-istilah baru selama masa pandemi Covid-19. Fokus riset ini melakukan pengamatan atas penggunaan istilah tersebut di media massa online khususnya pada kanal berita nasional terhadap pemaknaan istilah-istilah baru selama masa pandemi Covid-19. Sugiono (2005) mendefinisikan bahwa penelitian kualitatif lebih cocok digunakan untuk jenis penelitian yang memahami tentang fenomena sosial dari perspektif partisipan. Secara sederhana, dapat pula diartikan sebagai penelitian yang lebih cocok digunakan untuk meneliti kondisi atau situasi objek penelitian. 
Penelitian kualitatif tidak hanya upaya mendeskripsikan data, akan tetapi dengan mengutamakan hasil pengumpulan data dengan kriteria di antarnya; wawancara, observasi partisipasi, studi dokumentasi, dan triangulasi data. Proses deskripsi dan analisis data melalui beberapa tahapan, pertama display data, reduksi data, refleksi data, kajian emik (fenomena sosial berdasarkan penilaian dari masyarakat itu sendiri) dan etik (fenomena sosial berdasarkan penilaian di luar masyarakat itu sendiri) terhadap data, serta pengambilan kesimpulan. Sesuai dengan paradigma dalam penelitian kualitatif, bahwa peneliti akan mencoba memahami bagaimana individu meresapi makna dari dunia sekitarnya melalui pengalaman peneliti dan melakukan konstruksi pandangan tentang dunia di sekitarnya. Tujuannya, memberikan penjelasan secara eksplanatif dengan memahami ciri dan hubungan sistematis fenomena berdasarkan fakta di lapangan.

Untuk menunjang penelitian, proses analisis data dilakukan secara induktif, yakni menampilkan informasi latar penelitian secara utuh serta mampu menemukan pengaruh bersama yang dapat mempertajam hubungan antar konsep yang menjadi fokus penelitian. Pengujian keabsahan data akan dilaksanakan dengan teknik triangulasi. Peneliti akan mengumpulkan dan mengelompokkan data berdasarkan kebutuhan dan instrumen penelitian. Selain itu, tahapan lain adalah dengan mengumpulkan beberapa catatan tambahan dari penelitian lainnya yang memiliki relevansi dengan tema yang digunakan.

Secara umum, bahasa berkutat pada tiga hal yakni pikiran, perasaan, dan sikap. Dalam bahasa lain seperti yang dinyatakan oleh Kneller bahasa dalam kehidupan manusia mempunyai fungsi simbolik, emotif, dan afektif (Barrow \& Woods, 2006). Konsep interaksi simbolik muncul dengan ide dasar untuk membentuk makna yang berasal ari pikiran manusia (mind) mengenai diri (Self), dan hubungannya di tengah interaksi sosial. Tujuannya sebagai mediasi serta melakukan interpretasi makna yang muncul di masyarakat. Hal tersebut dipertegas melalui konsep Mind, Self, and Society yang digagas oleh Georger Herbert Mead.

Pikiran (Mind) adalah kemampuan menggunakan simbol yang mempunyai makna sosial yang sama, dimana setiap individu harus mengembangkan pkiran mereka melalui interaksi dengan orang lain. Diri (Self), kemampuan untuk merefleksikan diri setiap individu dari penilaian sudut pandang atau pendapat orang lain. Sedangkan masyarakat (society) aala jejaring hubungan sosial yang diciptakan, dibangun, dan dikonstruksikan oleh setiap individu yang terlibat dalam proses interaksi (Mead et al., 2015). Selanjutnya konsep ini dikembangkan oleh Erving Goffman sebagai 'dramaturgi' dalam 'The Presentation of Self' dengan penggunaan atribut bahasa sebagai elemen yang mendasari analisis dalam transformasi nilai-nilainya (Goffman, 2017).

Perkembangan teknologi ternyata memberikan dampak-dampak yang bersifat positif ataupun negatif, misalnya dibidang sosial, ekonomi, dan budaya. Adapun bahasa menjadi medium konstruksi yang membangun dimensi-dimensi tersebut. Sebagai contoh praktik penggunaan bahasa Inggris seperti yang telah disebutkan di atas, adalah fakta fenomena sosial yang sangat mudah dijumpai dan menjadi contoh kecil dari efek transformasi teknologi informasi. Kemunculan teknologi beserta seperangkat dampaknya merupakan konsekuensi logis yang harus diterima. Seperti yang diungkapkan oleh Merton (1936), resiko dan konsekuensi dapat muncul secara sengaja maupun tidak sengaja. Industri teknologi berkembang bersama zaman yang merangkak menuju peradaban modern. Dalam etika dan praktiknya hanya 
perkara relevansi dan kelaziman beradaptasi saja yang bisa menjadi celah untuk lebih bijak menghadapinya.

Oleh karena itu, untuk mendapatkan temuan yang relevan dalam riset ini maka akan menggunakan analisis konsep konstruksi bahasa dan kajian interaksionisme simbolik. Selain itu, teori dan konsep lain yang memiliki relasi dengan kajian ini akan dijadikan sebagai alat analisis tambahan. Di sisi lain, penelitian ini berusaha mengungkap bagaimana media dalam hal ini diwakili oleh pemerintah sebagai gugus tugas penanganan Covid-19 dan konstruksi bahasa Indonesia yang menjadi objeknya. Bahasa sebagai gagasan utama dalam penyampaian maksud dan tujuan dari komunikator kepada komunikan. Jika merujuk kepada konsep Lasswell (1940) dalam The Structure Function of Communication Society maka gagasan tersebut dapat dirumuskan dengan frase siapa yang berkata apa, di kanal apa, untuk siapa, dan dengan efek apa. Dalam konsep ini bahasa berperan sebagai pesan. Hal ini dapat dilihat dalam gambar di bawah ini.

Gambar 1. Konsep model komunikasi ala Harold Laswell

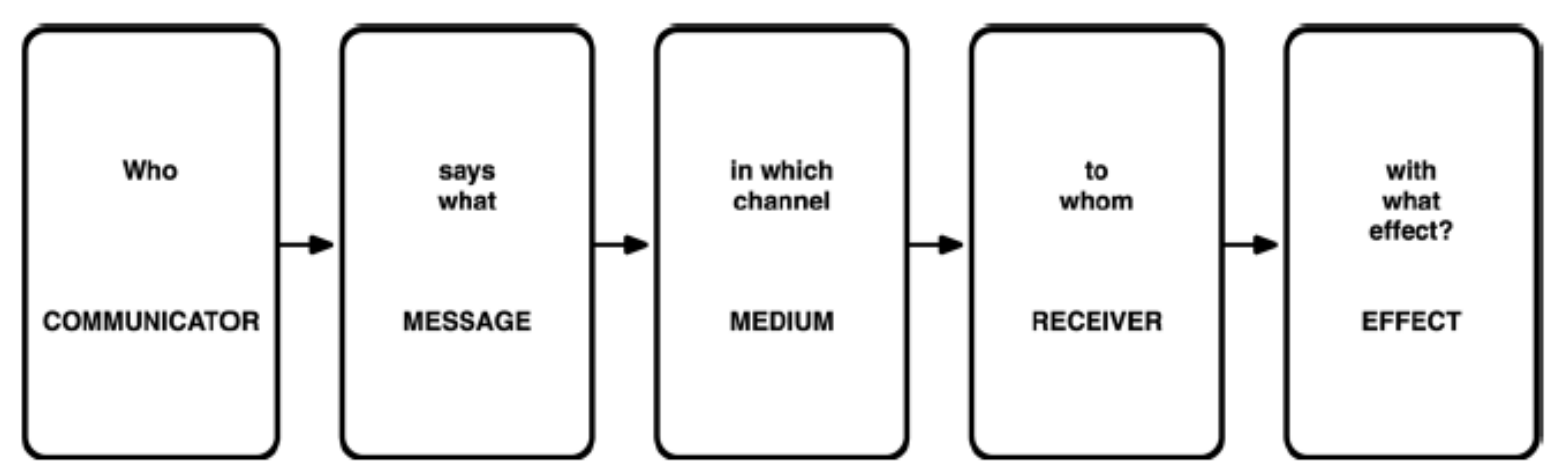

Sumber: Laswell (1940)

\section{Hasil dan Pembahasan}

Menurut Kushartanti dalam buku Pesona Bahasa, definisi bahasa adalah sistem tanda bunyi yang disepakati untuk dipergunakan oleh para anggota kelompok masyarakat tertentu dalam bekerja sama berkomunikasi, dan mengidentifikasikan diri (Kushartanti, 2005). Bahasa yang digunakan oleh manusia semakin berkembang seiring berjalannya waktu. Hal ini dimungkinkan terjadi melalui interaksi sosial yang membawa pengaruh positif dan negatif. Di antara pengaruh positifnya yakni banyak kosakata baru yang muncul dari suatu kelompok, bahkan suatu negara. (Junaidi, 2010). Adapun pengaruh negatifnya yakni gejala sebuah bahasa yang digunakan tidak pada tempatnya, sehingga seolah-olah dipaksakan agar sesuai dengan tren kekinian. Dalam hal ini contohnya adalah penggunaan bahasa Inggris yang seakan mewabah hingga masuk dalam pelbagai bidang ilmu khususnya bahasa. Ditambah lagi kondisi pandemi Covid-19 yang menambah khazanah bahasa khususnya peristilahan dalam dunia medis yang berkaitan dengan virus corona.

Bahasa Inggris memang tidak dapat dipungkiri kehadirannya dalam semua sendi kehidupan. Kemudahan dalam segi gramatika serta pengucapan membuat bahasa Inggris dapat secara mudah untuk dipelajari. Sehingga dimana-mana orang menggunakan bahasa Inggris sebagai bahasa pengantar komunikasi satu sama lain. Hal ini menyebabkan bahasa Inggris 
digunakan secara masif di berbagai belahan dunia, di semua bidang tak terkecuali bidang bahasa medis. Penggunaan bahasa Latin dan bahasa Inggris kerap digunakan dalam bidang medis mengingat fungsi dan kemudahan dalam penulisan dan struktur morfologisnya (Junaidi, 2010).

Perlintasan bahasa yang muncul akibat pandemi Covid-19 merupakan sebuah fenomena yang menarik untuk dikaji dari banyak sisi. Penulis akan fokus menggunakan pendekatan framing untuk mendedah fenomena ini karena keterbatasan waktu dan sudut pandang. Pendekatan teori Fairclough (2003) yang mengusung analisis wacana lebih cocok untuk mencoba merangkai sebuah bingkai peristiwa fenomena atau isu kekinian yang sedang terjadi. Studi fokus pada media-media nasional dalam penggunaan bahasa terkait pandemi sehingga akan terlihat mana saja media yang konsisten dengan penggunaan bahasa asli dan media yang menggunakan alih kode bahasa ke bahasa Indonesia. Fenomena keberagaman istilah ini perlu diberikan perhatian guna memastikan istilah yang digunakan dapat dipahami dan diimplementasikan oleh masyarakat karena terkait dengan kesejahteraan (Kasdan et al, 2020).

Penelitian ini merupakan gabungan antara disiplin ilmu komunikasi dan sosiologi sebagai akar ilmunya. Konsep interaksi simbolik diinterpretasikan melalui bahasa yang berlaku di masyarakat sebagai turunan dari fungsi bahasa itu sendiri. Jika mengambil rentang waktu sampel penelitan, maka peneliti mulai sejak awal pandemi Covid-19 masuk ke Indonesia yaitu medio Maret 2020 hingga Desember 2020. Hal ini untuk memudahkan pelacakan berita yang memuat istilah terkait pandemi serta pengaruhnya dalam tatanan sosial masyarakat.

Menurut Lanin (2019), fungsi bahasa secara garis besar terbagi menjadi tiga. Pertama, bahasa berfungsi sebagai alat komunikasi dan fungsi ini yang menjadi fungsi utama bahasa. Dalam tataran ini bahasa dibagi menjadi dua, yaitu bahasa lisan yang diejawantahkan melalui ujaran mulut dan bahasa tulisan yang diejawantahkan melalui aksara. Kedua, bahasa berfungsi sebagai tanda sosial. Dalam tataran ini, bahasa telah mengalami derivasi menjadi alat kontrol sosial. Artinya bahasa menjadi fungsi adaptasi manusia dalam lingkungan sosial (Andriani, 2015). Kata kunci yang utama dalam fungsi sosial ini adalah interaksi yaitu hubungan antara individu dan lingkungan psikis (Gerungan, 2010). Ketiga, fungsi bahasa sebagai alat ekspresi manusia. Dalam tataran ini, bahasa telah mengalami perlintasan panjang serta modifikasi bentuk formal ke informal karena proses turunan dari dua fungsi awal tersebut di atas.

Terkait fungsi-fungsi bahasa tersebut terdapat fenomena bahasa bernama fenomena xenoglossy yang mewabah sejak kemunculan internet di awal medio tahun 2000. Xenoglossy secara bahasa berasal dari perpaduan dua kata bahasa Yunani, 'xenos' yang bermakna aneh dan 'glossa' yang bermakna bahasa. Dalam istilah psikologi dapat diartikan sebagai kemampuan kontroversial seseorang dalam berbicara dan menulis dalam bahasa yang tak mereka pahami secara sadar atau tidak sadar (Arnas, 2019). Fenomena sejenis dalam bahasa psikologis disebut juga dengan juvenile delinquency sebagai padanan frase kenakalan remaja, yaitu sebuah ketakberdayaan kultural terhadap suatu realitas tatanan global yang notabene sering ditakar melalui idealitas kacamata kebudayaan Amerika yang diniagakan secara mendunia melalui musik, film, dan buku (Munsyi, 2005).

Bahasa memang selalu dinamis terkait dengan budaya sekitar yang berkembang. Artinya ketika bahasa mencari bentuk barunya, orang tak lagi mudah mengejeknya sebagai sebuah recehan belaka. Bahasa menjadi pertanda dari sesuatu hal yang lain, kecairan, kejutan yang tak 
tertebak, fenomena yang membingungkan. Bahkan lebih jauh, mungkin pula ini refleksi atas sebuah perlawanan, atas keajekan dan keresmian yang bertahan demikian lama. Boleh jadi pula bahwa ada gerilya diam-diam yang berupaya mendongkel dinginnya bahasa dan beserta orangorang tua generasi jaman dulu dan menghadirkan alternatif di sana. (Wadipalapa, 2021). Sehingga perubahan bahasa sejatinya adalah sesuatu yang lazim terjadi karena sifat bahasa yang dinamis mengikuti budaya setempat terkait ruang dan waktu.

Konsep bahasa klasik menurut segitiga retorika ala Ariestoteles secara garis besar terdiri dari tiga pokok pikiran utama yakni logos, ethos, dan pathos (Lutzke dan Henggeler, 2009). Konsep logos meliputi hal yang mendominasi alasan dalam penulisan yang dapat ditemukan dalam teks. Isinya berupa poin utama yang membentuk bangunan stuktur tulisan. Kemudian konsep ethos mewakili karakter si penulis atau dapat dikatakan sebagai peran penulis dalam argumentasi dan bagaimana argumentasinya dapat diterima atau tidak. Adapun yang terakhir yaitu konsep pathos merepresentasikan sisi emosi dan simpati dari penulis.

Gambar 2. Konsep Segitiga Retorika Bahasa

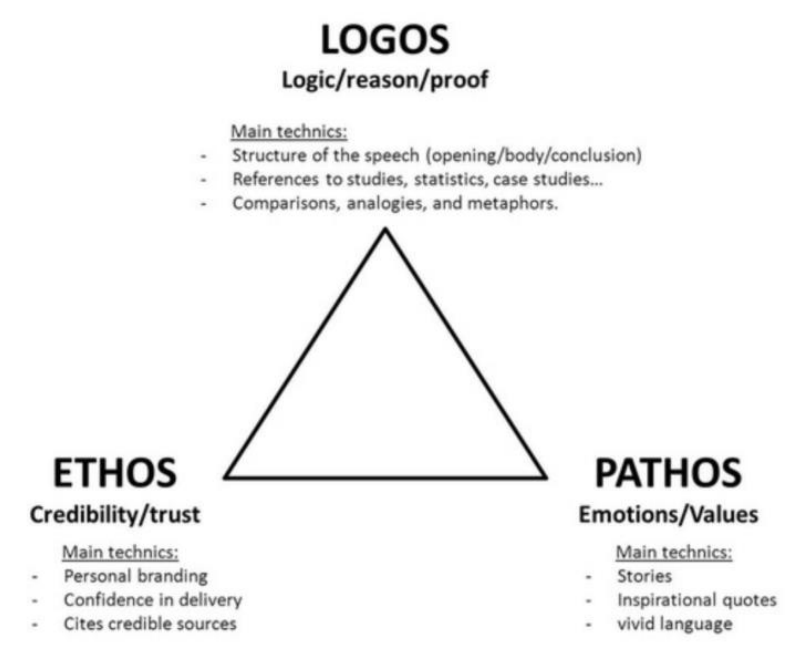

Sumber: Lutzke dan Henggeler, 2009

Secara linimasa historis, pandemi Covid-19 mewabah sekitar akhir tahun 2019 menjelang pergantian tahun 2020. Sebagaimana dilansir oleh situs resmi www.who.int milik WHO (World Health Organization), Covid-19 merupakan istilah dari virus SARS-Cov-2 yang diklaim sebagai virus baru pada 31 Desember 2019 dan menjadi viral yang disinyalir berasal dari Wuhan, Republik Rakyat Cina. Gejala awal virus ini yang menyerang sistem kekebalan tubuh dapat diidentifikasi melalui kenaikan suhu tubuh di atas $38^{\circ}$ Celcius yang ditandai dengan demam, batuk, dan kelelahan. Adapun profil virus SARS-Cov-2 dapat mengalami mutasi atau membentuk varian virus baru sehingga membutuhkan waktu sekitar 14 hari untuk bermutasi. Hal inilah yang mendasari gerakan 3M dengan tagar \#IngatPesanIbu yang populer digaungkan oleh grup musik Padi Reborn melalui jingle lagu bertajuk Ingat Pesan Ibu, yaitu memakai masker, mencuci tangan, dan menjaga jarak. Sebagian orang awam salah kaprah memaknai istilah corona dan Covid-19. Jika dirinci kedua istilah tersebut memiliki perbedaan. Istilah corona merujuk kepada penamaan label virus SARS-Cov-2, adapun istilah Covid-19 
merupakan singkatan dari Coronavirus Disease merujuk kepada wabah yang ditimbulkan oleh virus corona tersebut dan angka 19 merujuk kepada kode tahun ditemukan virus.

Dilansir dari kompas.com tercatat hingga per akhir Desember 2020 jelang pergantian tahun (26/12), jumlah pasien penderita Covid-19 mencapai angka 706.897 jiwa. Adapun jumlah pasien sembuh mencapai angka 576.693 jiwa. Sementara itu angka pasien meninggal mencapai angka 20.994 jiwa. Celakanya, Jakarta sebagai pusat ibukota pemerintahan menjadi zona merah paling signifikan dalam kasus positif corona. Pemberlakuan kebijakan semacam PSBB secara langsung telah memberikan dampak yang signifikan terhadap sektor perekonomian yang bergerak pada bidang manufaktur, pariwisata, perhotelan, dan transportasi. Selain itu, trauma dan kehilangan orang-orang yang disayangi, ketidakpastian kapan pandemi akan berakhir menyebabkan ketakutan, kepanikan, yang mempengaruhi kesehatan mental manusia (Sari, 2020).

Konsep Robert Merton mengenai konsekuensi tanpa tujuan (unintended consequency) dapat diaplikasikan dalam kasus media dan bahasa selama pandemi Covid-19 di Indonesia. Teori unintended consequency fokus kepada gejala sosial yang tidak terduga sebelumnya yang bersifat masif. Artinya belum ada fenomena sebelumnya yang berlangsung dalam kurun waktu cukup lama melibatkan pelbagai disiplin ilmu seperti yang dimunculkan oleh pandemi Covid19. Konsep unintended (tak disengaja) padan dengan kata unanticipated (tak terduga) dalam berbagai literatur (Zwart, 2015). Hal ini jika dikaitkan dengan kebijakan publik maka sejatinya kebijakan publik yang baik pada dasarnya tidak hanya terbatas soal satu sasaran kebijakan atau tujuan yang positif semata, tapi di sisi lain juga harus melihat konteks yang lebih besar, termasuk mengantisipasi bagaimana dampak negatif tak terelakkan yang ditimbulkannya.

Berdasarkan pengamatan penulis selama pandemi Covid-19, tercatat ada beberapa juru bicara dari pihak Badan Nasional Penanggulangan Bencana (BNPB) yang acapkali muncul di tayangan televisi. Jabatan juru bicara BNPB untuk pertama kali selama pandemi dijabat oleh Agus Wibowo setelah menggantikan Sutopo Purwo Nugroho yang meninggal dunia akibat kanker paru-paru. Adapun karena situasi dan kondisi yang darurat akhirnya pemerintah menetapkan Letjen TNI Doni Monardo sebagai Ketua Gugus Tugas Percepatan Penanganan Covid-19 sekaligus Kepala BNPB. Tercatat hampir setahun lamanya Doni Monardo wara-wiri muncul di televisi mewartakan angka-angka korban pandemi Covid-19 mulai dari data pasien terinfeksi, pasien meninggal, dan pasien sembuh. Bahkan Gugus Tugas Percepatan Penanganan Covid-19 sempat menggunakan influencer seperti dr. Reisa Broto Asmoro yang sebelumnya dikenal publik sebagai juara Putri Indonesia Lingkungan Hidup 2010 dalam salah satu acara pencarian bakat dan sempat pula mewakili Indonesia dalam kontes kecantikan Miss Internasional 2011. Bahkan pendakwah sekaliber (Alm.) Syekh Ali Jaber sempat dilibatkan pula dalam misi Gugus Tugas Percepatan Penanganan Covid-19 demi memberikan pencerahan kepada masyarakat melalui siraman rohani yang menyasar pada konteks spiritual.

Kebijakan-kebijakan yang ditempuh oleh satuan Gugus Tugas Percepatan Penanganan Covid19 melalui penyuluhan menggunakan simbol influencer cantik semacam dr. Reisa Broto Asmoro sampai ulama sekaliber (Alm.) Syekh Ali Jaber patut untuk dipertanyakan seberapa 
maksimal efektifitasnya. Mengingat kebijakan komunikasi semacam ini hanya menyasar pada jenjang atas tanpa ada tindak lanjut dari pemerintah.

Dalam rencana strategis BNPB disebutkan bahwa dalam rangka memenuhi amanat Undang-Undang Nomor 14 Tahun 2008 tentang Keterbukaan Informasi Publik, maka BNPB yang berfungsi sebagai focal point informasi penanggulangan bencana pada tahun 2013 telah menerbitkan Perka Nomor 9 Tahun 2013 tentang Pedoman Pengelolaan Informasi dan Dokumentasi (PPID) di Lingkungan BNPB. Saat ini, informasi yang disampaikan BNPB dapat diakses secara langsung dan terbuka melalui situs resmi BNPB. Informasi yang tersedia bagi publik di situs resmi tersebut meliputi dokumen rencana aksi, rencana strategis, Daftar Isian Pelaksanaan Anggaran (DIPA), laporan keuangan, penetapan kinerja, dan lain-lain. Seiring kasus Covid-19 yang semakin bertambah jumlahnya setiap hari, media mengambil peran signifikan dalam hal pemberitaan dengan menggunakan retorika gaya bahasa sesuai dengan ideologi masing-masing media. Penulis merangkum beberapa produksi istilah yang perlu dicatat terkait pandemi Covid-19 dalam uraian narasi paragraf. Adapun setelah proses inventaris kata-kata atau istilah yang digunakan semasa pandemi Covid-19 yang terdiri dari tiga kategori. Pertama, istilah yang terkait pandemi Covid-19 yang berhubungan dengan profil virus dan antivirus. Kedua, istilah yang terkait dengan pandemi Covid-19 yang berhubungan dengan aksi penanganan dan tindakan pemerintah. Ketiga, istilah yang terkait dengan pandemi Covid19 yang berhubungan dengan pasien atau korban Covid-19.

Istilah yang terkait pandemi Covid-19 yang berhubungan dengan profil virus dan antivirus yaitu corona atau Covid-19, yang berasal dari kata Coronavirus disease atau Covid19 /Corona D164G. Penjelasan terminology ilmiah singkatnya, virus ini merupakan mutasi virus corona yang ditemukan oleh Professor Nidom Foundation (PNF). Virus ini yang dilansir oleh Global Initiative on Sharing All Influenza Data (GISAID) ada di Indonesia sejak Maret 2020 terletak di dalam protein yang membentuk bentuk khusus (spike) berupa paku di permukaan virus corona sehingga menjadi pintu masuk untuk membobol sel manusia. Kemudian ada pula istilah epidemi yang mengacu pada penularan atau infeksi penyakit dalam skala yang lebih luas. Penyakit tak lagi hanya berada di satu atau beberapa wilayah tertentu. Suatu penyakit, misalnya Covid-19, melalui tahap epidemi terlebih dulu sebelum pandemi. Epidemi mengindikasikan perlunya peningkatan kewaspadaan di wilayah sekitar wabah. Adapun istilah pandemi adalah sebuah istilah yang berarti penyakit sudah menyebar ke seluruh dunia hingga sulit dikendalikan, hal ini sebagai antitesis dari istilah epidemi. Penularan antar manusia juga mengakibatkan kematian yang sangat besar, seperti yang terjadi pada Covid-19. Dalam tahap pandemi, negara bisa bertindak tegas untuk melindungi warganya supaya tidak tertular penyakit. Misal lockdown, PSBB, dan pembatasan akses keluar masuk lainnya. Ada istilah berikutnya yaitu flattening the curve (pelandaian kurva) adalah istilah untuk memperlambat penularan Covid-19. Metode ini meliputi peningkatan fasilitas kesehatan, social distancing, physical distancing, isolasi, dan karantina.

Lebih lanjut ada istilah vaksin yaitu suatu zat yang merupakan merupakan suatu bentuk produk biologi yang diketahui berasal dari virus, bakteri atau dari kombinasi antara keduanya yang dilemahkan. Vaksin diberikan kepada individu yang sehat guna merangsang munculnya antibodi atau kekebalan tubuh guna mencegah dari infeksi penyakit tertentu. Hal yang perlu digarisbawahi, imunisasi memberikan perlindungan kekebalan terhadap penyakit secara 
spesifik tergantung jenis vaksin yang diberikan. Istilah vaksin mulai populer sekitar akhir 2020 ketika wacana pemberian vaksin digadang-gadang oleh pemerintah Indonesia.

Kemudian terdapat istilah yang terkait dengan pandemi Covid-19 yang berhubungan dengan aksi penanganan dan tindakan pemerintah, terdapat istilah swab/ uji usap. Istilah ini digunakan untuk salah satu metode tes deteksi virus Covid-19 menggunakan alat khusus seperti kapas lidi yang diusapkan pada rongga nasofaring atau orofaring untuk mendapatkan lendir yang akan digunakan untuk sampel. Istilah kedua, PCR singkatan dari Polymerase Chain Reaction yaitu jenis pemeriksaan yang berguna untuk mendeteksi pola genetic (DNA dan RNA) dari suatu sel, kuman, atau virus, termasuk virus Covid-19. Tes PCR ini memiliki akurasi paling tinggi diantara tes Covid-19 lain. Istilah ketiga yaitu rapid test atau uji cepat, adalah sebuah metode tes menggunakan alat cartridge semacam kartu untuk mengambil darah dari pembuluh vena di ujung jari kita sebagai sampel. Rapid test berfungsi untuk mendeteksi antibodi dalam tubuh ketika terinfeksi virus. Sesuai dengan namanya, hasil dari rapid test ini dapat langsung diketahui dalam jangka waktu singkat yang umumnya hanya membutuhkan sekitar 15 menit. Istilah keempat yaitu rapid antigen dengan ilustrasi saat seseorang terinfeksi virus Covid-19, maka sistem kekebalan tubuh mereka akan mengenali virus tersebut sebagai antigen. Tes rapid antigen ini akan mendeteksi adanya antigen tersebut di dalam tubuh. Beberapa penelitian menunjukkan bahwa pemeriksaan tes dengan metode rapid antigen lebih akurat jika dibandingkan dengan metode rapid test biasa yang hanya mendeteksi antibodi, karena tes rapid antigen bisa mendeteksi langsung keberadaan antigen virus corona pada sampel, yang berasal dari saluran pernapasan.

Selain itu pemerintah juga mengeluarkan istilah terkait protokol kesehatan untuk menjaga jarak dengan istilah pertama yaitu physical distancing (pembatasan fisik) atau social distancing (pembatasan sosial). Kedua pembatasan ini merupakan salah satu langkah pencegahan dan pengendalian infeksi virus corona dengan menganjurkan orang sehat untuk membatasi kunjungan ke tempat ramai dan kontak langsung dengan orang lain. Sejak Jumat 20 Maret 2020 istilah social distancing sudah diganti dengan physical distancing oleh pemerintah. Ketika menerapkan social distancing, seseorang tidak diperkenankan untuk berjabat tangan serta menjaga jarak setidaknya satu meter saat berinteraksi dengan orang lain, terutama dengan orang yang sedang sakit atau berisiko tinggi menderita Covid-19. Pembatasan ketiga yaitu PPKM (Pemberlakuan Pembatasan Kegiatan Masyarakat). Istilah ini mulai digunakan oleh pemerintah sejak 11-25 Januari 2021 mencakup daerah Jawa-Bali seiring dengan kebijakan terkait kenaikan jumlah pasien Covid-19 di awal tahun baru 2021. Pembatasan keempat yaitu large-scale social restriction (LSSR) atau PSBB (Pembatasan Sosial Berskala Besar). Merupakan program pemerintah membatasi aktivitas warga demi mencegah kerumunan massa. Tercatat DKI Jakarta sebagai provinsi pertama yang memberlakukan aturan PSBB pada 7 April 2020.

Kemudian ada pula istilah karantina. Dikutip dari Badan Kesehatan Dunia WHO, karantina direkomendasikan untuk pasien terinfeksi virus corona namun tidak menunjukkan gejala. Karantina akan menekan risiko penyebaran dan peningkatan kasus virus corona. Karantina bisa dilakukan dengan isolasi mandiri di rumah selama 14 hari. Selama karantina yang wajib dilakukan adalah menerapkan pola hidup bersih, sehat, dan tidak bertemu dengan 
orang lain. Jika harus bertemu wajib menjaga jarak minimal satu meter dan menggunakan masker. Adapun untuk perubahan terbaru yakni istilah

Selain itu, ada beberapa contoh penerapan protokol kesehatan social distancing yang umum dilakukan sesuai anjuran WHO dan Kementerian Kesehatan Republik Indonesia terkait dengan tagar \#stayathome, yaitu WFH (Work from Home) atau kerja dari rumah. Kebijakan ini mengizinkan karyawan menyelesaikan pekerjaan dari rumah. Aturan WFH mirip belajar dari rumah bagi siswa sekolah atau ibadah di rumah. Kebijakan WFH memungkinkan penerapan social distancing dan physical distancing, sebagai usaha pencegahan penularan virus corona. Protokol ini biasanya diterapkan sesuai aturan lembaga terkait hingga kondisi menjadi lebih baik. Ada pula istilah yang dicanangkan oleh Kementerian Pendidikan yaitu belajar di rumah secara online bagi siswa sekolah dan mahasiswa, menunda pertemuan atau acara yang dihadiri orang banyak, seperti konferensi, seminar, dan rapat, atau melakukannya secara online lewat konferensi video atau teleconference, tidak mengunjungi orang yang sedang sakit, melainkan cukup melalui telepon atau video call. Self isolation atau isolasi mandiri adalah protokol yang mewajibkan setiap orang untuk tinggal di dalam rumah atau tempat tinggal masing-masing sambil melakukan upaya pembatasan fisik dengan orang lain. Pemerintah Indonesia menghimbau setiap orang untuk melakukan isolasi mandiri. Namun, protokol ini wajib diberlakukan pada kelompok tertentu, yaitu orang yang memiliki gejala Covid-19 seperti demam, batuk, dan sesak napas dan tidak memiliki penyakit penyerta, seperti diabetes, penyakit jantung, dan infeksi HIV, kemudian orang yang dicurigai atau sudah terkonfirmasi positif Covid-19, dan orang yang memiliki riwayat bepergian ke zona merah atau wilayah endemis Covid-19 dalam waktu 2 minggu terakhir, orang yang telah menjalani pemeriksaan rapid test Covid-19

Ada pula istilah screening, yang digunakan sebagai upaya verifikasi gejala dan potensi sebelum tes Covid-19. Menurut pengalaman pribadi penulis, seluruh rumah sakit di Jakarta menerapkan sistem ini sebelum pasien diizinkan untuk berinteraksi dengan tenaga medis rumah sakit. Beberapa rumah sakit yang memiliki kebijakan ketat terkait pandemi bahkan mewajibkan rapid test ketimbang hanya berupa screening saja terkait tindakan medis. Kemudian muncul istilah herd immunity yang digunakan untuk kekebalan kelompok yang tercapai bila beberapa orang dalam komunitas tahan terhadap serangan virus. Imunitas kelompok terjadi dengan pemberian vaksin pada masyarakat luas.

Kemudian istilah yang terkait dengan pandemi Covid-19 yang berhubungan dengan pasien, korban covid, calon pasien, atau eks pasien penyintas Covid-19, maka terdapat perlintasan istilah seperti istilah pertama yaitu ODP (Orang Dalam Pemantauan). Dikutip dari situs Kementerian Kesehatan Republik Indonesia, ODP biasanya adalah orang yang memiliki salah satu gejala Covid-19 yaitu gangguan pernapasan seperti batuk, pilek, sakit tenggorokan, dan sesak napas. Bagi ODP disarankan agar mengisolasi mandiri di rumah selama minimal 14 hari, adapun jika kondisi memburuk sebaiknya agar langsung dilarikan ke rumah sakit terdekat. Istilah kedua yaitu PDP (Pasien Dalam Pengawasan). PDP biasanya merupakan pasien yang sudah memiliki riwayat demam atau gangguan pernapasan serta pasien PDP memiliki riwayat perjalanan dan kontak dengan wilayah terinfeksi Covid-19. Istilah ketiga yaitu OTG (Orang Tanpa Gejala). Istilah yang digunakan untuk menandai orang yang terinfeksi virus corona namun tidak menunjukkan gejala tertentu. Istilah keempat adalah suspect. Istilah ini sempat 
digunakan untuk menandai pasien terkait virus corona. Pasien suspect menunjukkan gejala, pernah melakukan perjalanan, atau kontak dengan pasien Covid-19. Pasien suspect virus corona wajib melakukan swab test dan isolasi di rumah sakit. Hal ini memudahkan tindakan secepatnya, jika kondisi pasien makin buruk. Semua tindakan medis akan dilakukan untuk memperbaiki kondisi pasien secepatnya.

Pembaharuan berita terkait Covid-19 tercatat ada istilah baru yang tren awal 2021 yakni comorbid, atau singkatan dari comorbidity. Secara medis, istilah comorbidity merujuk kepada istilah penyakit bawaan lain selain penyakit utama yang diderita pasien. Menurut kamus Merriam Webster, istilah ini mulai populer sejak tahun 1970 sebagaimana seperti ungkapan CEO MWW Grup, Michael Kempner pada Majalah Forbes edisi 4 Maret 2021. Dilansir oleh data yang dimiliki oleh Kementerian Kesehatan Republik Indonesia melalui situs resminya tertanggal 21 Oktober 2020, bahwa kasus kematian akibat pandemi Covid-19 didominasi oleh kasus komorbid di Jawa Timur, Jawa Tengah, dan Sulawesi Selatan.

Terkait dengan hal-hal yang terjadi di atas, ada beberapa kasus yang sempat viral semasa pandemi Covid-19 (Mulyana, 2020) yaitu kerumunan massa di restoran cepat saji McDonalds Sarinah yang melanggar PSBB. Hal ini terjadi tanggal 10 Mei 2020 disertai kerumunan warga dengan alasan selebrasi dalam rangka peringatan hari terakhir operasional McDonalds Sarinah setelah 30 tahun. Kemudian ada juga insiden pembagian sanitizer bergambar Bupati Klaten, Sri Mulyani pada April 2020 yang disinyalir sebagai bentuk kampanye terselubung jelang Pilkada serentak. Tentunya hal semacam ini mengundang kontroversi terkait konteks politik dan ekonomi. Ada pula kasus penolakan dan pengambilan paksa jenazah Covid-19 yang dilakukan oleh keluarga korban Covid-19. Beberapa oknum keluarga korban bersikeras bahwa jenazah keluarga mereka tidak terkena virus corona dan layak untuk dimakamkan secara umum sebagaimana kondisi normal.

Selanjutnya tercatat ada kasus sejumlah aktivis masjid yang bersikeras ingin melaksanakan salat berjamaah di masjid, bahkan beberapa oknum ada yang tidak menggunakan masker dan tidak menerapkan protokol kesehatan dengan dalih agama. Kasus semacam ini sempat mencuat ke berbagai media sosial. Bahkan tercatat ada kasus sebaliknya yang terjadi di Masjid Al Amanah Harapan Indah Bekasi, ada jamaah masjid yang mendapat perlakuan tidak nyaman oleh oknum Dewan Keamanan Masjid (DKM) setempat karena telah menggunakan masker dan oknum tersebut mengklaim bahwa orang yang masuk masjid dijamin aman karena berargumentasi dengan ayat suci Alquran. Ada pula kasus viral yang menjadi sorotan publik yaitu panic buying yaitu situasi beli sembako, masker, dan sanitizer secara masif dan cepat namun terkesan tergesa-gesa yang terjadi di daerah Jakarta dan sekitarnya yang berakibat pada harga sanitizer yang melambung tinggi secara sporadis. Penulis juga mencatat kasus bunuh diri karena alasan Covid-19 di sejumlah negara. Hal ini mengundang berbagai diskursus dari banyak disiplin ilmu untuk mengkaji tren kematian mendadak akibat Covid-19.

Berkaca dari peristiwa di atas, media seharusnya menggunakan fungsi sebagai anjing penjaga atau watchdog dalam pengawasan kasus pandemi Covid-19. Menurut pantauan penulis, selama pandemi berlangsung pada Maret hingga Desember 2020, ada ragam tulisan dan berita yang tersebar di media baik cetak maupun digital menggunakan beragam pola dalam format bahasa penulisan. Secara garis besar penggunaan bahasa dalam ihwal komunikasi terkait pandemi Covid-19 terbagi menjadi tiga: Pertama, penggunaan bahasa Inggris yang disepakati 
oleh WHO sebagai badan kesehatan dunia yang menangani kasus Covid-19. Kedua, penggunaan bahasa Indonesia serapan bahasa Inggris. Ketiga, yaitu penggunaan bahasa Indonesia akronim dalam peristilahan pandemi Covid-19.

Jurnalistik menjadi salah satu bagian penting dalam perkembangan bahasa suatu negara, termasuk Indonesia. Perkembangan jurnalistik di Indonesia sangat berperan penting dalam perkembangan Bahasa Indonesia. Tidak dapat dipungkiri bahwa jurnalistik saat ini begitu pesat dan maju hingga memberikan banyak pengaruh dalam tata bahasa. Oleh sebab itu sejumlah pakar berpendapat bahwa peran jurnalistik memiliki fungsi penting dalam perkembangan Bahasa Indonesia saat ini salah satunya menyebarkan istilah baru (Rizal, 2020).

Sebagai contoh kerja jurnalistik, Lembaga Kantor Berita Nasional (LKBN) ANTARA yang diwakili oleh portal berita antaranews.com memilih ragam bahasa komunikasi yang lebih menggunakan nuansa Indonesia. Dapat dilihat pada pemilihan kata Uji Usap sebagai pengganti kata Swab Test dalam berita tertanggal Kamis 3 September 2020 "DKI Jakarta laksanakan prosedur baru uji usap sesuai pedoman Kemenkes". Senada dengan itu, Media Indonesia juga memilih padanan kata Uji Usap dalam pemberitaan tertanggal Selasa 27 Oktober 2020 yang memuat berita "Indonesia Butuh Lab Mampu Periksa Uji Usap".Dua kantor berita tersebut konsisten memberitakan pandemi Covid-19 menggunakan pilihan kata Uji Usap sebagai padanan kata Swab Test. Pilihan kata Uji Usap mencerminkan ideologi kedua media sebagai representasi Indoensia dalam penanganan kasus pandemi Covid-19.

Terkait dengan ideologi media, di belakangnya ada pilihan strategi komunikasi. Pilihan ini yang digunakan media untuk menyampaikan berita dari pemerintah kepada masyarakat. Ada beberapa teknik yang digunakan dalam pilihan strategi komunikasi (Arifin,1994). Pertama, yaitu teknik repetisi, yaitu mempengaruhi audiens menggunakan cara pengulangan pesan. Kedua, teknik kanalisasi yaitu metode mempengaruhi audiens dengan cara memahami dan meneliti pengaruh kelompok terhadap individu atau audiens. Ketiga, teknik informatif yaitu teknik mempengaruhi audiens dengan cara memberikan penjelasan atau penerangan. Kelima, teknik persuasif, yaitu teknik mempengaruhi audiens dengan pendekatan bujukan. Keenam, teknik edukatif yaitu metode mempengaruhi audiens melalui pernyataan umum yang dilontarkan, dan diwujudkan dalam bentuk pesan yang akan berisi pendapat-pendapat, faktafakta, dan pengalaman-pengalaman. Ketujuh, teknik koersif atau paksaan. Dalam teknik ini menggunakan cara paksaan kepada audiens untuk kemudian dimanifestasikan dalam bentuk peraturan, undang-undang, dan intimidasi-intimidasi.

Setelah mengelaborasi beberapa teknik tersebut di atas, maka penulis sampai pada hipotesis bahwa pemerintah seolah canggung untuk memaksa publik hingga level teknik koersif, yang berakhir dengan undang-undang. Mengingat fenomena Covid-19 termasuk kejadian luar biasa atau force majeur. Hal ini dapat dibuktikan pada ketidaktegasan pemerintah dalam menindak pelanggaran terkait himbauan di media. Dapat dikatakan dalam sisi ini, pemerintah bersikap tanggung dan tidak komperhensif.

Ketakutan atas akibat dari Covid-19 dibangun dengan konstruksi pemberitaan negatif seperti misalnya berita soal korban Covid-19 melalui angka-angka semata. Di sisi lain, media tidak menyajikan berita yang proporsional terkait fungsi edukasi guna menekan angka-angka tersebut. Hegemoni trauma komunal inilah yang digunakan oleh pemerintah untuk menciptakan 
sebuah konstruksi semu melalui corong pihak-pihak yang dianggap berkompeten dalam bidangnya.

Inkonsistensi media dalam pemberitaan Covid-19 menunjukkan suatu fenomena ketidakberhasilan pemerintah dalam upaya penyeragaman arus informasi. Terdapat hubungan antara agen sosial dan teks yang memiliki signifikansi serta berdampak sosial (Fairclough, 2003). Bahasa telah beralih fungsi menjadi sesuatu yang tidak netral dan hanya disepakati oleh segelintir pihak yang di dalamnya terkandung ideologi dan kekuasaan. Dalam sengkarut informasi media terkait Covid-19 bisa kita lihat dalam pemberitaan beberapa media yang turut serta mengambil peran. Fenomena semacam ini menunjukkan bahwa pemerintah hanya fokus menyasar pada masyarakat perkotaan terdidik yang berasal dari kelas menengah. Celakanya untuk memahami bahasa dan peristilahan Covid-19, seseorang harus memahami prasyarat tertentu (Surahmat, 2020).

Gejala eufemisme dalam pemberitaan bencana semacam ini menurut menjadi catatan bahwa pemerintah gagal dalam memilih strategi komunikasi yang tepat dan efektif. Ditambahkan pula bahwa hal tersebut menjadi indikasi kode ganda ekonomi dan kesehatan tanpa fokus yang jelas (Antony, 2016). Bahasa elitis yang dipilih oleh pemerintah menjadikan ruang ambigu semakin terbuka. Menurut Wahyuni (2020), hal ini menjadi sebab ekses media untuk membuka ruang diskursus baru bagi masyarakat untuk bersikap ambigu tanpa adanya panduan informasi yang jelas yang beresiko membawa kesalahpahaman di tengah krisis kolektif semacam pandemi Covid-19 ini. Strategi gaya bahasa yang digunakan oleh pemerintah cenderung ke arah sektor ekonomi dengan kode ganda sektor ekonomi dan kesehatan yang masih belum jelas.

Dalam konteks mitigasi bencana terdapat tugas jurnalistik standar yang harus dilakukan. Ada beban berat jurnalis pada waktu terjadi bencana mencakup tugas peliputan dengan tuntutan akurasi, profesionalisme, serta etika dan sekaligus upaya memikirkan keamanan diri dan jiwa. (Prajarto, 2005). Di sisi lain, antusiasme yang terbingkai dalam pemberitaan selama bencana di sisi lain menjadikan salah kaprah dalam mengantisipasi bencana. Celakanya, di sisi lainnya justru media informasi dijadikan sebagai sistem informasi bencana. Hal ini berakibat pada kebingungan publik dalam memperoleh informasi terkait bencana

Adapun jika mengacu ke penanganan bencana di Amerika, terdapat semacam asosisasi penanganan bencana yang menggunakan standar operasional yang tertib. Sebagai contoh American Bar Assosiation State and Local Government menyediakan suatu ceklis sebagai acuan format gugus tugas dalam menangani bencana. Artinya ada keseragaman tindakan dan pola standar yang menggunakan bahasa yang disepakati bersama tanpa ada ambiguitas. Di dalam ceklis tersebut terdapat pelbagai pertimbangan tentang isu, kebijakan, peraturan, dan aktor-aktor yang bisa dirujuk serta koordinasi antar lembaga. Kesadaran komunal dan kolektif terhadap bencana sebagai suatu konsekuensi kolektif sudah menjadi sebuah kesiapan pemerintah yang didukung oleh lembaga yang berkompeten di bidangnya masing-masing. Arus informasi dan akses dapat dipahami oleh masyarakat dengan mudah dan merata kepada seluruh lapisan.

Reputasi media dan pekerjanya dalam suatu bencana dapat dipandang dari dua sisi. Pertama, media harus mampu menghadirkan informasi yang dibutuhkan oleh publik meski kebijakan redaksional yang sesungguhnya dapat diarahkan kepada lebih memperbesar atensi 
publik pada korban bencana. Kedua, media tidak hanya berperan sebagai pewarta informasi namun juga dalam aksi langsung penanganan bencana.

\section{Simpulan}

Dari pemaparan di atas, penulis mengambil beberapa kesimpulan terkait dinamika pandemi dan proses produksi bahasa selama pandemi, yakni: pertama, inkonsistensi media dalam pemberitaan Covid-19 menunjukkan suatu fenomena ketidakberhasilan pemerintah dalam upaya penyeragaman arus informasi. Kesimpangsiuran arus informasi yang disebabkan miskomunikasi persepsi dan konsepsi pemerintah yang dijalankan oleh agen informasi sehingga membuka ruang diskursus baru sehingga memungkinkan terjadinya misinformasi berjenjang dari pemerintah hingga lapisan masyarakat paling bawah.

Kedua, dari sekelumit pemaparan penelitan ini terkait dengan perlintasan bahasa asing yang dalam hal ini penggunaan bahasa medis dalam kaitannya dengan komunikasi kesehatan, terdapat inklusifitas bahasa yang seharusnya dicerna oleh pemerintah dan disosialisasikan melalui media-media yang ramah lingkungan misalnya melalui seminar daring atau sejenisnya melalui media sosial yang penggunannya meningkat selama pandemi. Hal demikian menjadi semacam solusi atas ketimpangan arus informasi yang hanya menyasar kepada masyarakat ekonomi kelas menengah, sehingga terjadi pemerataan arus informasi berimbang ke seluruh lapisan masyarakat. Dalam hal ini jurnalis sebagai garda terdepan arus informasi mengambil inisiatif sebagai jembatan antara pemerintah dan masyarakat sekaligus menjalankan fungsi edukasi jurnalisme kepada khalayak secara komperhensif dan menghindari sekaligus memberantas pemberitaan hoax dan sejenisnya.

Ketiga, manajemen bencana harus menggunakan acuan proporsional yang melibatkan sistem informasi yang melibatkan berbagai pihak kompeten sehingga dapat menjadi referensi valid bagi seluruh pihak tanpa adanya bias. Kebijakan terkait pandemi bersifat kolektif terkait dengan hajat hidup masyarakat, oleh karena itu pemerintah hendaknya menjadi rujukan utama dalam hal informasi dan mitigasi bencana.

\section{Referensi}

Andriani, Susi \& Jatiningsih, Oksiana. (2015). Strategi Adaptasi Sosial Siswa Papua di Kota Lamongan. Jurnal Kajian Moral dan Kewarganegaraan Vol 02 Nomor 03 Tahun 2015 hal 530-544. Surabaya: Universitas Negeri Surabaya.

Arifin, Anwar. (1994). Strategi Komunikasi, Sebuah Pengantar Ringkas. Bandung: CV Armico.

Arnas, Benny. (2019). Xenoglossy dan Sastra. Prosiding Seminar Nasional Bulan Bahasa (Semiba). Bengkulu: Jurusan Pendidikan Bahasa dan Seni Universitas Bengkulu

Barrow, R., \& Woods, R. (2006). An introduction to philosophy of education. In An Introduction to Philosophy of Education. https://doi.org/10.4324/9780203969953

Effendi, Onong. (2011). Ilmu Komunikasi: Teori dan Praktek. Bandung: PT Remaja Rosdakarya.

Fairclough, Norman. (2003). Analyzing Discourse: Textual Analysis for Social Research. Lancashire: University of Lancester.

Kasdan, J., Baharuddin, R., \& Shamsuri, A. S. (2020). Covid-19 dalam Korpus Peristilahan Bahasa Melayu: Analisis Sosioterminologi (Covid-19 in the Corpus Of Malay 
Terminology: A Socio-terminological Analysis). GEMA Online ${ }^{\circledR}$ Journal of Language Studies, 20(3), 221-241. https://doi.org/10.17576/gema-2020-2003-13

Kementerian Komunikasi dan Informasi Republik Indonesia. (2008). Undang-Undang Nomor 14 Tahun 2008 tentang Keterbukaan Informasi Publik Retrieved from https://jdih.kominfo.go.id/produk_hukum/view/id/172/t/undangundang+nomor+14+tah un++2008+tanggal+30+april+2008

Kushartanti. (2005). Pesona Bahasa: Langkah Awal Memahami Linguistik. Jakarta: PT Gramedia Pustaka Utama.

Lanin, Ivan. (2019). IndonesiaX 11: Komunikasi Efektif pada Era Digital. Bandung

Goffman, E. (2017). Interaction ritual: Essays in face-to-face behavior. In Interaction Ritual: Essays in Face-to-Face Behavior. https://doi.org/10.4324/9780203788387.

Junaidi, Romika. (2010). Analisis Morfologis Kata Serapan Bahasa Rusia Iklan Paket Pariwisata Pulau Bali (The Morphological Analysis for Loan Words in Russian in The Advertisements for The Package of Tourist Services in Bali). Undergraduate thesis. Depok: Universitas Indonesia.

Lutzke \& Henggeler. (2009). The Rhetorical Triangle Understanding and Using Logos, Ethos, and Pathos. Indiana: School of Liberal University of Indiana.

Herbert, Antony. (2016). The Role Euphemisms in Healthcare Communication. Journal of Healthcare Communication Vol.1 no.2:14. London: UK ImedPub Ltd.

Merriam-Webster. (n.d.). Comorbid. In Merriam-Webster.com dictionary. Retrieved July 8, 2021, from https://www.merriam-webster.com/dictionary/comorbid

Merton, RK. (1936). Puritanism, Pietism, and Science. First Published January 1, 1936 Research Article https://doi.org/10.1111/j.1467-954X.1936.tb01317.x. SAGE Publications.

Moleong, LJ. (2000). Metodologi Penelitian Kualitatif. Bandung: Remaja Rosda Karya.

Muller et al. (2020). COVID-Twitter-BERT: A Natural Language Processing Model to Analyse COVID-19 Content on Twitter. New York: Cornell University.

Mulyana, Deddy. (2020). Webinar Peluang dan Tantangan Di Tengah Wabah Pandemi Covid19, Magister Ilmu Komunikasi Universitas Budi Luhur, Rabu 17 Juni 2020. Jakarta. Universitas Budi Luhur. Retrived from https://www.youtube.com/watch?v=ux0TGQr3BM

Munsyi, Alif D. (2005). Bahasa Menunjukkan Bangsa. Jakarta: Kepustakaan Populer Gramedia.

Murwani, Santosa. (2005). Metodologi Penelitian Ilmiah, Jakarta: PPS UHAMKA.

Mead, G. H., Huebner, D. R., \& Joas, H. (2015). Mind, self, and society (C. W. Morris, Ed.). University of Chicago Press. https://doi.org/10.7208/chicago/9780226112879.001.0001.

Prajarto, Nunung. (2005). Komunikasi: Cermatan Perkembangan. Jurnal Ilmu Sosial dan Ilmu Politik Universitas Gadjah Mada vol.9 no.2. Yogyakarta: JSP. https://doi.org/10.22146/jsp.11036

Prajarto, Nunung. (2008). Bencana, Informasi, dan Keterlibatan Media. Jurnal Ilmu Sosial dan Ilmu Politik Universitas Gadjah Mada vol.11 no.3. Yogyakarta: JSP. https://doi.org/10.22146/jsp.10989

Rizal, Yon. (2020). Peran Media dalam Menguatkan Penggunaan Bahasa Indonesia yang Baik dan Benar. Retrieved from https://riauone.com/global/Peran-Media-dalam-MenguatkanPenggunaan-Bahasa-Indonesia-yang-Baik-dan-Benar

Sari, Y. I. (2020). Sisi Terang Pandemi Covid-19. Jurnal Ilmiah Hubungan Internasional, 8994. Bandung: Universitas Katolik Parahyangan. 
Surahmat. (2020). Akademisi: Pemerintah Masih Gunakan Bahasa Langit dalam Komunikasi Covid-19. Retrieved from https://theconversation.com/akademisi-pemerintah-masihgunakan-bahasa-langit-dalam-komunikasi-Covid-19-134805

Wadipalapa, Rendy. (2021). Dari Gelay, Membagongkan, dan Demi Alek. Retrieved from https://kalikata.id/2021/03/dari-gelay-membagongkan-dan-demi-alek/

Zwart, Frank. (2015). Unintended but not Unanticipated Consequences. Leiden: Leiden University. DOI http://dx.doi.org/10.1007/s11186-015-9247-6 